\title{
ANALYSIS OF THE RISK OF CONTAMINATION BY METALS IN AREAS OF SOLID URBAN WASTE DISPOSAL
}

\author{
Valdenira. C. da Silva ${ }^{1 *}$, Pedro Herlleyson. G. Cardoso ${ }^{2}$, Cleidiane. G. Lima ${ }^{3}$, Rubens. C. de \\ Castro $^{3}$; Crisiana. A. Nobre ${ }^{3}$ and Maria Aparecida. L. Milhome ${ }^{4 *}$ \\ 1 Universidade Federal do Cariri, Juazeiro do Norte, Ceará, Brasil \\ 2 Departamento de Engenharia Agrícola, Universidade Federal do Ceará, Fortaleza- Ceará, Brasil \\ 3 Fundação Núcleo de Tecnologia Industrial do Ceará, Fortaleza, Ceará, Brasil \\ ${ }^{4}$ Instituto Federal de Educação, Ciência e Tecnologia do Ceará, Limoeiro do Norte, Ceará, Brasil
}

Received 22 November 2020; received in revised form 10 December 2020; accepted 30 December 2020

\begin{abstract}
:
The inadequate disposal of solid urban waste has been of concern, due to the possibility of environmental contamination by various toxic substances, such as heavy metals. The study aims to analyze the concentration of heavy metals in soil and water samples collected around the municipal solid waste (MSW) open dumpsite, Iguatu, Ceará, Brazil. The analysis of risk to human health was determined using Hazard Quotient (HQ). The results showed the presence of heavy metals in concentrations higher than those established by current legislation. The concentration of metals in the soil and water samples were found in the following order, respectively: $\mathrm{Fe}>\mathrm{Zn}>\mathrm{Mn}>\mathrm{Cu}>\mathrm{Pb}>$ $\mathrm{Cr}$ and $\mathrm{Fe}>\mathrm{Mn}>\mathrm{Zn}>\mathrm{Ni}>\mathrm{Cu}>\mathrm{Cr}>\mathrm{Cd}>\mathrm{Co}$. However, HQ values indicate that the level of these metals may have little or no adverse health effects. The results suggest the continuous monitoring of the environmental matrices, to avoid the increase of contamination and the risk to human health.
\end{abstract}

Keywords: Artificial aeration; constructed wetlands; nutrients removal; rural sanitation; wastewater treatment

(C) 2020 Journal of Urban and Environmental Engineering (JUEE). All rights reserved.

\footnotetext{
*Correspondence to: Valdenira. C. da Silva. E-mail: valdeniracarlos88@gmail.com
} 


\section{INTRODUCTION}

The inadequate disposal of solid urban waste has been a concern in recent years, due to the possibility of contamination of soil and water resources. Developing countries have sought strategiest to implement effective waste management (Cetrulo et al., 2018; Abdel-Shafy and Mansour, 2018).

In Brazil, the National Solid Waste Policy (PNRS), Law 12.305/2010, contains important instruments for the control of the main environmental, social and economic problems arising from the inadequate handling of solid waste (Brasil, 2010). Brazilian Institute of Geography and Statistics (IBGE) related that in 2017 half of the 5570 Brazilian municipalities did not have an integrated plan for waste management (Costa \& Dias, 2020).

In this context, waste management includes rules and laws that aim to minimize environmental damage. The municipal plan for the integrated management of solid waste consists of a diagnosis of the current situation of the set of waste generated in the municipality and defines guidelines, strategies and goals to be developed, related to environmental management, treatment, recycling and final disposal of waste (Brazil, 2010).

The presence of heavy metals in environmental matrices can cause several effects to ecosystems and human health (Reza \& Singh, 2010; Arantes et al., 2016; Swarnalatha et al., 2013). The toxic effects of metals depend on the degree of exposure. Metals such as mercury, lead, cadmium, chromium, manganese and zinc can cause damage to the central nervous system, the hepatic, renal and skeletal systems. Manganese is essential, however, in excess it is associated with neurological diseases and behavioral disorders. High levels of copper cause gastrointestinal symptoms, such as diarrhea, abdominal pain and nausea (Cavallet, et al., 2013). A study conducted by Li et al. (2013) aimed to quantify traces of metals and to map the spatial distribution of health risk caused by these elements in the Henan-Liaocheng Irrigation Area (HLIA) in China. The results show that the average the sum of the hazard ratios ( $\Sigma$ HQs) exceeded the generally acceptable level of risk recommended by the USEPA, with a maximum of $\Sigma$ HQs of 3.79. Horta et al., (2011) estimated the risk of contamination by cadmium (Cd) through fish ingestion by the population of Sepetiba Bay-SE, Brazil. The probability and risk due to cadmium intake was assessed using the hazard ratio (HQ). The risk for cadmium intake was 110 times greater than that found in population control, which may be related to kidney diseases.

The inadequate disposal of Urban Solid Waste can interfere with the levels of toxic metals in the ecosystem (Gouveia, 2012; Tucker et al., 2020). The main routes of exposure to these contaminants are soil dispersion and leachate percolation, reaching water resources.
Several studies have cited the contamination of toxic metals in water sources and soil (Ahmad \& Goni, 2010; Souza et al., 2016; Silva et al., 2018). Silva et al. (2018) carried out research to determine the concentrations of $\mathrm{Cd}, \mathrm{Cu}, \mathrm{Mn}, \mathrm{Ni}, \mathrm{Pb}$ and $\mathrm{Zn}$ in waters used for human and animal consumption and in the irrigation of vegetables in the municipality of Camocim de São Félix-PE, Brazil. According to the results of the study, the analyzed waters presented concentrations of $\mathrm{Cd}(>$ $\left.0.001 \mathrm{mg} \mathrm{L}^{-1}\right), \mathrm{Ni}\left(>0.025 \mathrm{mg} \mathrm{L}^{-1}\right)$ and $\mathrm{Pb}\left(>0.01 \mathrm{mg} \mathrm{L}^{-}\right.$ $\left.{ }^{1}\right)$ higher than the maximum permitted levels by Brazilian law, indicating the need for a preventive monitoring program and immediate intervention actions for sources of contamination. Sabiá et al., (2015) studied the influence of the leachate produced by the "garbage dump" on the water quality of the Salgado River Basin, Ceará, Brazil. According to the authors, the metals Cadmium, Silver and Nickel at all collection points were in concentrations above the limits allowed by CONAMA Resolution 357/05 and CONAMA 430/11. Kanmani \& Gandhimathi (2013) evaluated the concentration of heavy metals in soil samples collected around the open solid urban waste dump (MSW), Ariyamangalam, Tiruchirappalli, Tamilnadu. The concentration of heavy metals in the collected soil sample was found in the following order: $\mathrm{Mn}>\mathrm{Pb}>\mathrm{Cu}>$ $\mathrm{Cd}$, indicating that there is appreciable contamination of the soil by leachate migration from an open dumping site.

For about 30 years, the disposal of solid waste from the city of Iguatu, Ceara, Brazil has been done in open dumpsite, which may compromise the quality of life of the population. This work aims to expand the discussion on environmental pollution by heavy metals from the analysis of water and soil samples located around of the open dumpsite and to assess the risk to human health using Hazard Quotient (HQ).

\section{MATERIAL AND METHODS}

\section{Local of study and sampling}

The municipality of Iguatu is located in the CenterSouth Region of the state of Ceará at latitude 06 $21^{\circ} 34$ "South and at longitude $39^{\circ} 17^{\prime} 55^{\prime \prime}$ West, with an area of $1,029,002 \mathrm{~km}^{2}$ and an average population of 102,614 thousand inhabitants. The caatinga is the predominant vegetation in the region and the soils are podzolic, litolic, alluvial and vertisol (Ibge, 2017)

Since 1989, the "dump" has been installed next to the CE-282 highway, Chapadinha, CE. According to Ibge (2017), the main sources of water in the city of Iguatu are part of the Upper Jaguaribe basin, the rivers: Jaguaribe and Trussu; streams Carnaúba, Antônico, da Serra and many others. The rainfall in the municipality is 1079 millimeters per year, with rains concentrated from January to May. 
Table 1. Soil $\left(\mathrm{P}_{\mathrm{S} 1}, \mathrm{P}_{\mathrm{S} 2}, \mathrm{P}_{\mathrm{S} 3}, \mathrm{P}_{\mathrm{S} 4}\right)$ and water $\left(\mathrm{P}_{\mathrm{W} 1}, \mathrm{P}_{\mathrm{W} 2}, \mathrm{P}_{\mathrm{W} 3}\right.$ and $\left.\mathrm{P}_{\mathrm{W} 4}\right)$ collection points in the municipality of Iguatu-CE

\begin{tabular}{cl}
\multicolumn{2}{c}{ Geographic Coordinates } \\
\hline Sampling & Soil \\
& $6^{\circ} 22^{\prime} 51.20^{\prime \prime} \mathrm{S} / 39^{\circ} 15^{\prime} 4.00^{\prime \prime} \mathrm{O}$ \\
$\mathrm{P}_{\mathrm{S} 1}$ & $6^{\circ} 22^{\prime} 50.20^{\prime \prime} \mathrm{S} / 39^{\circ} 15^{\prime} 3.90^{\prime \prime} \mathrm{O}$ \\
$\mathrm{P}_{\mathrm{S} 2}$ & $6^{\circ} 22^{\prime} 49.40^{\prime \prime} \mathrm{S} / 39^{\circ} 15^{\prime} 4.30^{\prime \prime} \mathrm{O}$ \\
$\mathrm{P}_{\mathrm{S} 3}$ & $6^{\circ} 22^{\prime} 48.30^{\prime \prime} \mathrm{S} / 39^{\circ} 15^{\prime} 4.20^{\prime \prime} \mathrm{O}$ \\
$\mathrm{P}_{\mathrm{S} 4}$ & Water \\
& $6^{\circ} 22^{\prime} 44.24 " \mathrm{~S} / 39^{\circ} 15^{\prime} 15.32^{\prime \prime} \mathrm{O}$ \\
$\mathrm{P}_{\mathrm{W} 1}$ & $6^{\circ} 22^{\prime} 40.53^{\prime \prime} \mathrm{S} / 39^{\circ} 14^{\prime} 56.75 " \mathrm{O}$ \\
$\mathrm{P}_{\mathrm{W} 2}$ & $6^{\circ} 23^{\prime} 15.51^{\prime \prime} \mathrm{S} / 39^{\circ} 15^{\prime} 22.24 " \mathrm{O}$ \\
$\mathrm{P}_{\mathrm{W} 3}$ & $6^{\circ} 23^{\prime} 14.58^{\prime \prime} \mathrm{S} / 39^{\circ} 15^{\prime} 12.68^{\prime \prime} \mathrm{O}$ \\
$\mathrm{P}_{\mathrm{W} 4}$
\end{tabular}

Soil and water samples were collected during the period 2016/2017, in areas susceptible to contamination by solid urban waste disposed of inappropriately in the municipality of Iguatu-CE, Brazil. The soil samples $\left(\mathrm{P}_{\mathrm{S} 1}, \mathrm{P}_{\mathrm{S} 2}, \mathrm{P}_{\mathrm{S} 3}, \mathrm{P}_{\mathrm{S} 4}\right)$ were collected in a $20 \mathrm{~cm}$ column. The samples were packed in plastic bags and sent for analysis. The water samples $\left(\mathrm{P}_{\mathrm{W} 1}, \mathrm{P}_{\mathrm{W} 2}, \mathrm{P}_{\mathrm{W} 3}\right.$ and $\left.\mathrm{P}_{\mathrm{W} 4}\right)$ were stored in polypropylene bottles, previously sanitized and transported to the chemistry laboratory of the Federal Institute of Science and Technology of the Ceará- IFCE and kept refrigerated until the moment of the analysis.

\section{Sample pre-treatment}

The soil samples were first submitted to an acid digestion process following the methodology described by Method 3050b (USEPA, 1996) About $0.2 \mathrm{~g}$ of soil was weighed on an analytical balance and transferred to an Erlenmeyer. A $10 \mathrm{ml}$ volume of $0.1 \mathrm{M} \mathrm{HCl}$ was added to the vessel. The mixture was then subjected to constant stirring, at room temperature $\left( \pm 25^{\circ} \mathrm{C}\right)$ for about 2 hours. After acid digestion, the mixture was filtered and transferred to a $50 \mathrm{ml}$ volumetric flask and the volume was measured with distilled water. All samples were analyzed in duplicate. Water samples were acidified with nitric acid $\left(\mathrm{HNO}_{3}\right)$, according to the Method 200.7 (USEPA, 1982) A volume of $2.20 \mathrm{~mL}$ of $\mathrm{HNO}_{3}$ was added in $100 \mathrm{~mL}$ of water sample and then identified and stored under refrigeration for later analysis of metals. All samples were analyzed in duplicate.

\section{Metal analysis}

The determination of metals $(\mathrm{Cd}, \mathrm{Co}, \mathrm{Cr}, \mathrm{Cu}, \mathrm{Fe}, \mathrm{Mn}$, $\mathrm{Ni}, \mathrm{Cr}$ and $\mathrm{Zn}$ ) in soil samples were performed by Atomic Absorption Spectrometry - AAS (VarianZeeeman, model 640-Z). Standard solutions containing metals in the concentration range of $0.05-5.0 \mathrm{mg} . \mathrm{L}^{-1}$ were used for the calibration curves. The limits of quantification (LOQs) were $0.05 \mathrm{mg} . \mathrm{L}^{-1}$ for $\mathrm{Mn}, \mathrm{Co}, \mathrm{Ni}$, $\mathrm{Cu}, \mathrm{Cd}$, and $0.01 \mathrm{mg} . \mathrm{L}^{-1}$ for $\mathrm{Pb}, \mathrm{Cr}$ and $\mathrm{Zn}$. The level of metals $(\mathrm{Cd}, \mathrm{Co}, \mathrm{Cr}, \mathrm{Cu}, \mathrm{Fe}, \mathrm{Mn}, \mathrm{Ni}, \mathrm{Cr}$ and $\mathrm{Zn})$ in the water samples were determined by Spectrophotometry of Optical Emission with Plasma Inductively Coupled ICP-OES (model ICAP 6000 series, Thermo Scientific). The results were analyzed using the Iteva Control Center software. Calibration curves were prepared in the concentration range between $0.005-2 \mathrm{mg} . \mathrm{L}^{-1}$. The limits of quantification (LOQs) were $0.001 \mathrm{mg} \cdot \mathrm{L}^{-1}$ for the metals analyzed.

\section{Health risk assessment}

The health risk assessment study was based on the determination of the Hazard Quotient (HQ) according to the guidelines of the United States Environmental Protection Agency (USEPA, 1989). Chronic daily intake (ICD) and HQ were determined using equations 1 and 2 (USEPA 1989; Wu et al. 2009):

CDI (oral $)=\left(C_{W} \times I_{w} \times E F \times E D\right) /\left(B_{W} \times A T\right)$

\section{$\mathrm{HQ}=\mathrm{CDI} / \mathrm{RfD}$}

where $\mathrm{CDI}=$ Chronic daily intake, $\mu \mathrm{g} . \mathrm{Kg}^{-1} \cdot \mathrm{day}^{-1} ; \mathrm{Cw}$ : average concentration of trace metal in water, $\mu \mathrm{g} . \mathrm{L}^{-1}$; $\mathrm{IR}_{\mathrm{W}}$ : water ingestion rate, $2{\mathrm{~L} . d a y^{-1}}^{-1} \mathrm{EF}$ : exposure frequency, day/year; ED: exposure duration, 70 years; BW: average body weight, $70 \mathrm{~kg}$; AT: averaging time, for noncarcinogens, days (Zabin et al., 2008); RfD is the reference dose for different analytes, expressed in $\mu \mathrm{g}$. $\mathrm{Kg}^{-1}$.day ${ }^{-}$(USEPA, 2012).

\section{RESULTS AND DISCUSSION}

\section{Soil Analysis}

Higher levels of $\mathrm{Fe}, \mathrm{Zn}$ and $\mathrm{Mn}$ metals were verified in the soil samples, as shown in the Fig. 2. The concentrations of heavy metals present in the soil samples were compared with the guiding values of soil quality regarding the presence of chemical substances established by CONAMA Resolution 420/2009, described in Table 1.

According to the Resolution, Quality Reference values (VRQ) correspond to the concentration of a certain substance that defines the natural quality of the soil. This value may vary from State to State and it is the duty of each one to present these values, however in the State of Ceará they do not yet present these estimated values. Prevention values (VP) consist of values that limit a certain substance in the soil and if exceeded, it is necessary to monitor it. Intervention (VI) values are values that determine potential risks, human health, direct or indirect, considering a standardized exposure scenario. The results in Table 2 showed higher concentrations to $\mathrm{Fe}$ element, varying between 204,1-1229,3 mg/L. The $\mathrm{Zn}$ value found in PS3 ( $\mathrm{Zn}=$ $\left.402.23 \mathrm{mg} \cdot \mathrm{Kg}^{-1}\right)$ exceeded the prevention value $(\mathrm{PV}=$ 
$300 \mathrm{mg} \mathrm{Kg}^{-1}$ ). The same was verified for copper in PS2 $\left(\mathrm{Cu}=109.1 \mathrm{mg} . \mathrm{Kg}^{-1}\right)$ and PS3 (117.1 $\left.\mathrm{mg} \cdot \mathrm{Kg}^{-1}\right)$ exceeding the prevention value $\mathrm{VP}=60 \mathrm{mg} \mathrm{Kg}^{-1}$, indicating that there is a change in the soil quality. Copper is one of the most important metals industrially, an excellent conductor of electricity is currently used for the production of conductive materials.

The metals $\mathrm{Cd}$, Co and $\mathrm{Ni}$, were not present $(<\mathrm{LQ})$ in the samples investigated in the soil near the dump of Iguatu-CE. Fe and Mn metals do not yet have limits established by the CONAMA 420/2009 legislation. The data indicate that the levels of this metal are being altered due to the human anthropic action in the garbage dump. $\mathrm{Cu}$ and $\mathrm{Mn}$ were present in all samples, except in the PS1 sample, with higher concentrations in PS3 (117.1 and $132.2 \mathrm{mg} . \mathrm{Kg}^{-1}$ respectively). $\mathrm{Pb}$ was detected in all samples $\left(5.0-45.0 \mathrm{mg} . \mathrm{Kg}^{-1}\right)$, but within the limits established by the guiding values for soil (VP and VI residential). Lead is a highly toxic metal, in addition to damaging the environment, it is harmful to the brain and nervous system, in addition to affecting the blood, kidneys, digestive and reproductive systems.

The metal Chromium was detected only in PS3 and PS4, with levels from 8.8 to $18.2 \mathrm{mg} . \mathrm{Kg}^{-1}$, respectively. Marques (2011) detected a similar level of $\mathrm{Cr}$ in the soil $(0-20 \mathrm{~cm})$ of the landfill in Campo Belo-MG $(21.09 \mathrm{mg}$ $\left.\mathrm{Kg}^{-1}\right)$ and Elói Mendes-MG (20.72 $\left.\mathrm{mg} \mathrm{Kg}^{-1}\right)$. Chromium is a heavy metal, has a cumulative effect and can cause various damages to the health of humans and animals.

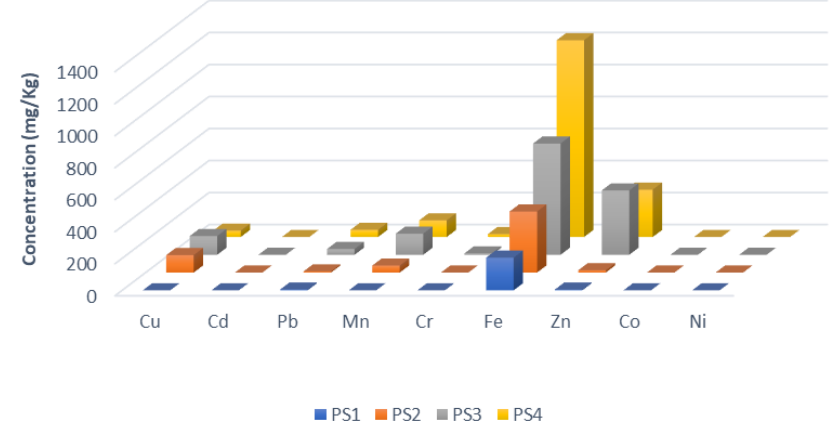

Fig. 2 Concentration of metals in $\mathrm{mg} \cdot \mathrm{kg}^{-1}$ in soil samples

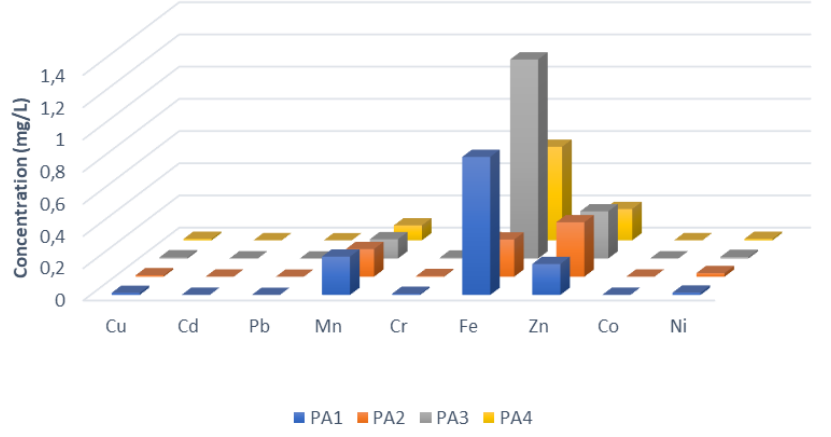

Fig. 3 Metals analyzed (mg. $\left.\mathrm{L}^{-1}\right)$ in water $\left(\mathrm{P}_{\mathrm{W} 1}, \mathrm{P}_{\mathrm{W} 2}, \mathrm{P}_{\mathrm{W} 3}\right.$ and $\left.\mathrm{P}_{\mathrm{W} 4}\right)$

\section{Analysis of metals in water}

Among the heavy metals analyzed in this study, Mn, $\mathrm{Zn}$ and $\mathrm{Fe}$ showed higher levels in water samples from manancials located near the Iguatu dump. Figure 3 shows the concentrations verified for the elements analyzed in the water samples. Table $\mathbf{1}$ shows the average concentration of metals obtained at each sampling point and the maximum limits established by national and international legislation (Brasil, 2005; Brasil, 2011; Eu, 1998; Epa, 2019).

The analysis of water samples from sources close to the Iguatu-CE dump showed the presence of $\mathrm{Mn}$ (0.093-0.238 mg. $\left.\mathrm{L}^{-1}\right)$ and $\mathrm{Zn}\left(0.192-0.338 \mathrm{mg} . \mathrm{L}^{-1}\right)$, in concentrations above the maximum allowed by the resolution CONAMA 357/05 (Class 2). The levels of metals detected can be related to the infiltration of the leachate produced in the decomposition of the garbage, causing the alteration in the water quality of the water sources in the region.

A previous study conducted by Abreu (2014) detected traces of Mn (0.14 to $\left.0.15 \mathrm{mg} . \mathrm{L}^{-1}\right)$ and $\mathrm{Zn}$ ( 0.04 to $\left.0.05 \mathrm{mg} . \mathrm{L}^{-1}\right)$ in a lake close to the dump in Iguatu-CE, however the levels found still fit within the established standards of CONAMA 357/05. Comparing these results with those of the present research, it appears that there was a significant increase in contamination by these metallic elements. The detected Cd concentrations $\left(0.0001 \mathrm{mg} . \mathrm{L}^{-1}\right)$ in the water samples were within the acceptable range. For the element $\mathrm{Ni}$, the highest concentration found was at point two (P2) $0.0238 \mathrm{mg} . \mathrm{L}^{-1}$, however these values found at the sampling points investigated were below the limit (0.025 mg. L $\left.{ }^{-1} \mathrm{Ni}\right)$ (Conama, 2005). Research developed by Anjos (2015) reported contamination by $\mathrm{Cd}$ and $\mathrm{Ni}$ in the waters of the Rio Curu-CE, at levels ranging from $0.00010-0.00103 \mathrm{mg} . \mathrm{L}^{-1}$ and $0.0002-$ $0.0038 \mathrm{mg} . \mathrm{L}^{-1}$, respectively.

High concentrations of Fe were found in this study, ranging from 0.231 to $1.236 \mathrm{mg} . \mathrm{L}^{-1}$, being above the $\mathrm{EU}$ acceptable value. Higher levels of $\mathrm{Fe}$ were observed in P1, P3 and P4, exceeding the limits of CONAMA, MS, EU and EPA. Fe is a chemical element that does not present much risk to health, but can have effects on water quality when taken together $\left(\mathrm{Fe}^{2+}\right.$ and $\mathrm{Mn}^{2+}$ form soluble in water). These elements are considered by the United States Environmental Protection Agency (EPA), Canada, the European Union and the Ministry of Health-Brazil as secondary contaminants capable of altering organoleptic standards and water potability. $\mathrm{Cu}$ was detected at all points in concentrations close to the established limit of the legislation (CONAMA 357/2005) of 0.009 $\mathrm{mg} . \mathrm{L}^{-1}$, reaching the maximum value in P1 0.013 mg. $\mathrm{L}^{-1}$. Traces of $\mathrm{Co}$ and $\mathrm{Cr}$ were detected in all samples analyzed. $\mathrm{Pb}$ was not detected in this study. 
Table 2. Concentration of soil samples in $\mathrm{mg}^{\mathrm{kg}-{ }^{1}}$ and Quality Reference Values-QRV, prevention values-PV and intervention values-IV (residential) established by CONAMA.

\begin{tabular}{|c|c|c|c|c|c|c|c|}
\hline \multirow[b]{2}{*}{ Metal } & \multicolumn{4}{|c|}{ Concentration (mg/Kg) } & \multicolumn{3}{|c|}{ Conama 420/2009 } \\
\hline & PS1 & PS2 & PS3 & PS4 & QRV & PV & IV \\
\hline $\mathrm{Cu}$ & $<$ LOQ & 109.1 & 117.1 & 39.8 & $E$ & 60 & 400 \\
\hline $\mathrm{Cd}$ & $<\mathrm{LOQ}$ & $<\mathrm{LOQ}$ & $<\mathrm{LOQ}$ & $<\mathrm{LOQ}$ & $E$ & 1.3 & 8 \\
\hline $\mathrm{Pb}$ & 5.0 & 7.5 & 36.2 & 45.0 & $E$ & 72 & 300 \\
\hline $\mathrm{Mn}$ & $<\mathrm{LOQ}$ & 43.6 & 132.0 & 104.2 & $E$ & - & - \\
\hline $\mathrm{Cr}$ & $<\mathrm{LOQ}$ & $<$ LOQ & 8.8 & 18.2 & $E$ & 75 & 300 \\
\hline $\mathrm{Fe}$ & 204.1 & 381.6 & 695.1 & 1229.3 & $E$ & - & - \\
\hline $\mathrm{Zn}$ & 4.6 & 14.7 & 402.2 & 295.8 & $E$ & 300 & 1000 \\
\hline $\mathrm{Co}$ & $<\mathrm{LOQ}$ & $<\mathrm{LOQ}$ & $<\mathrm{LOQ}$ & $<\mathrm{LOQ}$ & $E$ & 25 & 65 \\
\hline $\mathrm{Ni}$ & $<\mathrm{LOQ}$ & $<\mathrm{LOQ}$ & $<\mathrm{LOQ}$ & $<\mathrm{LOQ}$ & $E$ & 30 & 100 \\
\hline
\end{tabular}

$*<$ LOQ: Limiton of Quantification; $\mathrm{E}=$ to be defined by the State.

Table 3. Average concentration of metals analyzed in water samples in mg. $\mathrm{L}^{-1}$

\begin{tabular}{|c|c|c|c|c|c|c|c|c|}
\hline \multirow{2}{*}{ Metal } & \multicolumn{4}{|c|}{ Concentration $(\mathrm{mg} / \mathrm{L})$} & \multirow{2}{*}{$\begin{array}{c}\text { Conama } \\
357 / 05\end{array}$} & \multirow{2}{*}{ MS 2.914/11 } & \multirow{2}{*}{$\mathbf{E U}$} & \multirow{2}{*}{ EPA } \\
\hline & PW1 & PW2 & PW3 & PW4 & & & & \\
\hline $\mathrm{Cu}$ & 0.0132 & 0.0091 & 0.0086 & 0.0094 & 0.009 & 2.000 & 2.000 & 1.300 \\
\hline $\mathrm{Cd}$ & 0.0017 & 0.0013 & 0.0018 & 0.0018 & 0.001 & 0.005 & 0.005 & 0.005 \\
\hline $\mathrm{Pb}$ & $<\mathrm{LOQ}$ & $<\mathrm{LOQ}$ & $<\mathrm{LOQ}$ & $<\mathrm{LOQ}$ & 0.010 & 0.010 & 0.010 & 0.005 \\
\hline Mn & 0.2380 & 0.1720 & 0.1200 & 0.0930 & 0.100 & 0.100 & 0.050 & 0.050 \\
\hline $\mathrm{Cr}$ & 0.0079 & 0.0040 & 0.0064 & 0.0082 & 0.050 & 0.050 & 0.050 & 0.100 \\
\hline $\mathrm{Fe}$ & 0.8570 & 0.2312 & 1.2363 & 0.5810 & 0.300 & 0.300 & 0.200 & 0.300 \\
\hline $\mathrm{Zn}$ & 0.1926 & 0.3384 & 0.2938 & 0.1941 & 0.180 & 5.000 & - & 5.000 \\
\hline Co & 0.0015 & 0.0011 & 0.0016 & 0.0010 & 0.050 & - & - & - \\
\hline $\mathrm{Ni}$ & 0.0143 & 0.0230 & 0.0137 & 0.0091 & 0.025 & 0.070 & 0.020 & - \\
\hline
\end{tabular}

$*<$ LQ: Limit of Quantification; Conama 357/05 Class 2

Contamination of heavy metals has been associated with improper disposal of solid waste in the dump. Manganese is used in the manufacture of paints, ceramics, glass, welding electrodes, they are present in the waste deposited in the dump. The effects of this metal found at high levels can cause respiratory tract infection and pneumonitis from irritation. Its systemic toxicity is more common in chronic exposure through inhalation and ingestion, where the most pronounced effects are due to prolonged exposure to contaminated environments reaching the central nervous system. High concentrations of $\mathrm{Mn}$ can cause serious damage to humans, such as decreased motor movements, mental and emotional disorders.

\section{Health risk assessment}

$\mathrm{RfD}_{\text {oral }}$ values for trace metals and the health risk assessment study is summarized in table 4. The calculated CDI values of metals for oral intake showed values between 0.0286 to $35.3229 \mu \mathrm{g}$. $\mathrm{Kg}^{-1}$. day ${ }^{-1}$. The non-cancerous effects of different metals were determined by calculating the risk quotient (HQ), which indicates the probability of adverse health effects. However, the results of the present study indicate that the level of these metals (maximum value of 0.34) may represent few or no adverse health effects $(\mathrm{HQ}<1)$ for the population of Iguatu-CE by oral water intake. Research conducted by Karim (2011) obtained similar results for risk assessment for metals in drinking water in the Karachi region, Pakistan.

Table 4. Analysis of risk of contamination by metals in water

\begin{tabular}{|c|c|c|c|c|c|c|c|c|c|}
\hline \multirow[b]{2}{*}{ Metal } & \multirow{2}{*}{$\begin{array}{c}* \mathrm{RfD}^{-1} \\
\left(\text { ug. } \mathrm{Kg}^{-1} \cdot \mathrm{dav}^{-1}\right)\end{array}$} & \multicolumn{4}{|c|}{ Chronic daily intake ( $\left.\mu \mathrm{g} . \mathrm{Kg}^{-1} . \mathrm{day}^{-1}\right)$} & \multicolumn{4}{|c|}{ Hazard Quotient } \\
\hline & & $\mathrm{CDI}_{1}$ & $\mathrm{CDI}_{2}$ & $\mathrm{CDI}_{3}$ & $\mathrm{CDI}_{4}$ & $\mathrm{HQ}_{1}$ & HQ 2 & HQ 3 & HQ 4 \\
\hline $\mathrm{Cu}$ & 40 & 0.3771 & 0.2600 & 0.2457 & 0.2686 & 0.0094 & 0.0065 & 0.0061 & 0.0067 \\
\hline $\mathrm{Cd}$ & 0.5 & 0.0486 & 0.0371 & 0.0514 & 0.0514 & 0.0971 & 0.0743 & 0.1029 & 0.1029 \\
\hline $\mathrm{Pb}$ & 1.4 & NA & NA & NA & NA & NA & NA & NA & NA \\
\hline $\mathrm{Mn}$ & 20 & 6.8000 & 4.9143 & 3.4286 & 2.6571 & 0.3400 & 0.2457 & 0.1714 & 0.1329 \\
\hline $\mathrm{Cr}$ & 3 & 0.2257 & 0.1143 & 0.1829 & 0.2343 & 0.0752 & 0.0381 & 0.0610 & 0.0781 \\
\hline $\mathrm{Fe}$ & 300 & 24.4857 & 6.6057 & 35.3229 & 16.6000 & 0.0816 & 0.0220 & 0.1177 & 0.0553 \\
\hline $\mathrm{Zn}$ & 300 & 5.5029 & 9.6686 & 8.3943 & 5.5457 & 0.0183 & 0.0322 & 0.0280 & 0.0185 \\
\hline Co & NA & 0.0429 & 0.0314 & 0.0457 & 0.0286 & NA & NA & NA & NA \\
\hline $\mathrm{Ni}$ & 20 & 0.4086 & 0.6571 & 0.3914 & 0.2600 & 0.0204 & 0.0329 & 0.0196 & 0.0130 \\
\hline
\end{tabular}

*USEPA, 1989; Wu et al., 2009 


\section{CONCLUSION}

Analysis of soil samples from the region around open dumpsite of Iguatu-CE, Brazil, indicate high concentrations of $\mathrm{Fe}, \mathrm{Zn}$ and $\mathrm{Mn}$. In addition, the levels of $\mathrm{Zn}$ and $\mathrm{Cu}$ remained above the prevention values established by Brazilian legislation. The elements $\mathrm{Pb}$, $\mathrm{Mn}, \mathrm{Cr}$ were also detected in soil. The elements $\mathrm{Zn}, \mathrm{Fe}$, $\mathrm{Mn}, \mathrm{Cu}$ and $\mathrm{Cd}$ showed values above that allowed by water legislation. According to the results of soil and water metals obtained, the research suggests that the level of these identified metals is likely to have little or no adverse health effects, in view of verifying that the hazard ratio is less than one, indicating low risk contamination by metals. Therefore, the data show that the dump has been contributing to the pollution of these springs. Thus, this study contributes to assist environmental agencies in controlling the quality of water in the region and in the continuous monitoring of toxic metal levels in water sources.

Acknowledgment The authors would like to thank NUTEC - Ceara Industrial Technology Foundation for providing the infrastructure for metal analysis and IFCE, CNPq and FUNCAP for the financial support for the research.

\section{REFERENCES}

Abdel-Shafy, H.I., Mansour, M.S.M., (2018). Solid waste issue: Sources, composition, disposal, recycling, and valorization. Egyp $\begin{array}{lllll}\text { J. } & \text { Petrol. } & 27 & \text { (1), } & 1275-1290\end{array}$ https://doi.org/10.1016/i.ejpe.2018.07.003.

Abreu, M.K.F., (2014). Análise dos Níveis de Metais Pesados em um Lago nas Proximidades do Lixão do Município de Iguatu-Ce. 42 f. Monografia (Graduação em Licenciatura em Química) Instituto Federal de Educação, Ciência e Tecnologia do Ceará campus Iguatu, Iguatu, Ceará.

Ahmad, J.U., Goni. M.A., (2010). Heavy metal contamination in water, soil, and vegetables of the industrial areas in Dhaka, Bangladesh. Environ Monit Assess. 166 (1), 347-357. https://doi.org/10.1007/s10661-009-1006-6.

Anjos, D.C., (2015). Diversidade microbiana e de teores de metais pesados em solos e nas águas superficiais ao longo do rio curu. 108 f. Tese (Doutorado em Solos e Nutrição de Plantas) Universidade Federal do Ceará, Fortaleza, Ceará.

Arantes, F., Savassi, L.A., Santos, H. B., Gomes, M.V.T., Bazzoli, N., (2016). Bioaccumulation of mercury, cadmium, zinc, chromium, and lead in muscle, liver, and spleen tissues of a large commercially valuable catfish species from Brazil. An Acad Bras Cienc. $\quad 88$ (1), 137-147. https://doi.org/10.1590/00013765201620140434

Brasil, (2005). Resolução do Conselho Nacional do Meio Ambiente $n^{\circ} 357$ de 2005. Dispõe sobre a classificação dos corpos de água e diretrizes ambientais para o seu enquadramento, bem como estabelece as condições e padrões de lançamento de efluentes. Ministério do Meio Ambiente, Brasília, Distrito Federal. http://portalpnqa.ana.gov.br/Publicacao/RESOLUCAO CONAM A n 357.pdf

Brasil, (2011). Portaria do Ministério da Saúde n. ${ }^{\circ} 2.914$ de 2011. Dispõe sobre normas de potabilidade de água para o consumo humano. Ministério da Saúde, Brasília, Distrito Federal. https://bvsms.saude.gov.br/bvs/saudelegis/gm/2011/prt2914_12_1 2 2011.html.

Brasil, (2010). Lei $n^{\circ} 12.305$ de 2010. Institue a Política Nacional de Resíduos Sólidos. Ministério do Meio Ambiente, Brasília, Distrito Federal. $\quad$ http://www.planalto.gov.br/ccivil 03/ ato20072010/2010/lei/112305.htm.

Cavallet, E.L., Carvalho, S.G., Fortes, N. P., (2013). Heavy metals in the waste and in the water discharge area of municipal solid waste. Rev. Ambient. Água. 8 (1), 229-238. https://doi.org/10.4136/ambi-agua.1155.

Cetrulo,T.B., Marques, R.C., Cetrulo, N.M., Pinto, F.S., Moreira, R.M., Mendozábel-Cortés, A.D., Malheiros, T.F., (2018). Effectiveness of solid waste policies in developing countries: A case study in Brazil. Journal of Cleaner Production. 205 (1), 179187. https://doi.org/10.1016/j.jclepro.2018.09.094.

Costa. I.M. Dias. M.F, 2020. Evolution on the solid urban waste management in Brazil: A portrait of the Northeast Region. Energy $\begin{array}{llll}\text { Reports, } & 6 & \text { (1), } & \text { 878-884. }\end{array}$ https://doi.org/10.1016/j.egyr.2019.11.033.

EPA., (2019). US Environmental Protection Agency. National Primary Drinking Water Regulations. https://www.epa.gov/ground-water-and-drinking-water/nationalprimary-drinking-water-regulations.

EU, (1998). Directiva 98/83/CE, do Parlamento Europeu e do Conselho, de 03 de novembro de 1998. Relativa à qualidade da água destinada ao consumo humano. European Union. (JO L 330 de 5.12.1998, p. 32). https://eur-lex.europa.eu/legalcontent/PT/TXT/PDF/?uri=CELEX:01998L0083$20151027 \&$ from $=\mathrm{EN}$

Gouveia, N., (2012). Resíduos sólidos urbanos: impactos socioambientais e perspectiva de manejo sustentável com inclusão social. Ciênc. saúde coletiva, 17 (6), 1503-1510. https://doi.org/10.1590/S1413-81232012000600014.

Horta, M.A.P., Ferreira, A.P., Luzardo, A.J.R., Brignol, V., Brasil, V.I., Faro, A.R.M.C., Pinto, J., (2011). Risk analysis of cadmium intake by fish consumers in a sub-tropical coastal lagoon, sepetiba bay-se, Brazil. Rev. Bras. Prom. Saude, 24 (1), 46-53. https://doi.org/10.5020/18061230.2011.

IBGE, 2017. Instituto Brasileiro de Geografia e Estatística. http://www.cidades.ibge.gov.br.

Kanmani, S., Gandhimathi, R., (2013). Assessment of heavy metal contamination in soil due to leachate migration from an open dumping site. Appl Water Sci. 3 (1), 193-205. https://doi.org/10.1007/s13201-012-0072-z.

Karim, Z., (2011). Risk Assessment of Dissolved Trace Metals in Drinking Water of Karachi, Pakistan. Bull Environ Contam Toxicol. 86 (1), 676-678. https://doi.org/10.1007/s00128-0110261-8.

Li, J., Li, F.D., Zhang, Q.Y., Zhao, G.S., Liu, Q., Song, S., (2013). Groundwater trace metal pollution and health risk assessment in agricultural áreas. Understanding Freshwater Quality Problems in a Changing World, AHS Publ. 361 (1), 250-256. https://www.researchgate.net/publication/261524747 Groundwat er trace metal pollution and health risk assessment in agricul tural areas.

Marques, R.F.P.V., (2011). Impactos ambientais na disposição de resíduos sólidos urbanos no solo e na água superficial em três municípios de Minas Gerais. 96 f. Dissertação (Mestrado em Recursos Hídricos em sistemas Agrícolas) Universidade Federal de Lavras, Lavras, Minas Gerais. http://repositorio.ufla.br/jspui/handle/1/3047.

Reza, R.; Singh, G., (2010). Heavy metal contamination and its indexing approach for river water. Int. J. Environ. Sci. Technol. 7 (1), 785-792. https://doi.org/10.1007/BF03326187.

Sabiá, J.R., Silva, D.L., Barros, G.D.T., Santos, Y.T.C., Sobreira Junior, F.A.V., Lima, A.F.O., (2015). Contaminação da Bacia do 
Rio Salgado por Influência do Chorume e Possível Tratamento Através de Biossorventes. Caderno de Cultura e Ciência, 14 (1), 174-186. http://dx.doi.org/10.14295/cad.cult.cienc.v14i1.899.

Swarnalatha, K.; Letha, J.; Ayoob, S., (2013) Ecological Risk Assessment of a tropical Lake System. Journal of Urban and Environmental Engineering, v.7, n.2 p.323-329. DOI: 10.4090 / j Budap.2013.v7n2.323329

Silva, L.S., Galindo, I.C.L., Nascimento, C.W.A., Gomes, R.P., Freitas, L., Oliveira, I.A., Campos, M.C.C., Cunha, J.M., (2018) Metais pesados em águas utilizadas para consumo humano e irrigação de culturas. Rev. Ambient. Água. 13 (4), e1999. https://doi.org/10.4136/ambi-agua.1999.

Souza, A.O., Castro, A.H.S., Silva, N., Braga, E.A. S., Milhome, M.A.L., (2016). The Discharge of Effluents and the Contamination by Toxic Metals and Organic Matter in Lake of Semiarid Northeast, Brazil. Holos. 7 (1), 179-193. https://doi.org/10.15628/holos.2016.4892.

Tucker, E.L., Chickering, G.W., Spreadbury, C.J., Laux, S.J., Townsend, T.G., (2020). A componential approach for evaluating the sources of trace metals in municipal solid waste. $\begin{array}{llll}\text { Chemosphere. } & 260 & \text { (1), } & 1-10 .\end{array}$ https://doi.org/10.1016/j.chemosphere.2020.127524.

USEPA., (1996). Method 3050B: Acid Digestion of Sediments, Sludges, and Soils. United States Environmental Protection
Agency, Washington, DC. https://www.epa.gov/esam/epamethod-3050b-acid-digestion-sediments-sludges-and-soils.

USEPA., (1982). Method 200.7. Determination of metals and trace elements in water and wastes by inductively coupled plasmaatomic emission spectrometry. United States Environmental Protection Agency, Washington, DC. https:/www.epa.gov/sites/production/files/201506/documents/epa-200.7.

USEPA, (1989). Office of Water Regulations and Standard: Guidance manual for assessing human health risks from chemically contaminated, fish and shellfish U.S. United States Environmental Protection Agency. Environmental Protection Agency, Washington, DC.

USEPA, (2012). EPA Region III Risk-Based Concentration (RBC) Table 2008 Region III, 1650 Arch Street, Philadelphia, Pennsylvania 19103. United States Environmental Protection Agency, Washington, DC.

Wu, B., Zhao, D.Y., Jia, H.Y., Zhang, Y., Zhang, X.X., Cheng, S.P., (2009). Preliminary Risk Assessment of Trace Metal Pollution in Surface Water from Yangtze River in Nanjing Section, China. Bull Environ Contam Toxicol. $82 \quad$ (1), 410. https://doi.org/10.1007/s00128-009-9673-0. 